\title{
Nurses' Perception toward Talent Management and its Relationship to their Work Engagement and Retention
}

\author{
Samia S. Elhaddad ${ }^{1}$, Sanaa M. Safan ${ }^{2}$ and Shimaa E. Elshall ${ }^{3}$ \\ ${ }^{1}$ B.SC in nursing sciences, ${ }^{2}$ Assistant Professor of Nursing Administration, ${ }^{3}$ Lecturer of \\ Nursing Administration, Faculty of Nursing, Menoufia University
}

\begin{abstract}
Background: Talented employees create differential value and make contributions to organizations. Talent management has been advocated as an important strategy to engage and retain their employees. Purpose: The purpose of this study was to assess nurses' perception toward talent management and its relationship to their work engagement and retention. Design: A descriptive correlational research design was conducted at Menoufia University Hospital at Shebin-ELkom. Sampling: A convenience sample of 400 nurses was included in this study. Results: It was revealed that nurses had low level of perception towards talent management, more than half of the studied nurses had low work engagement levels, and also the majority of studied nurses had a low level of retention. Conclusion: There was a positive highly statistical significant correlation between nurses' perception toward talent management, their work engagement, and retention. Recommendation: Strategies and policies are required to develop the necessary vision to engage and retain talented nurses.
\end{abstract}

Key Words: Nurses' retention, Talent management, and Work engagement.

\section{Introduction}

In today's dynamic world full of change, organizations must adapt to environmental change and grow and reach higher levels of quality health care. So, they need ongoing developing production methods, processes, and services (Dehkordy, Haydari, and Iravani, 2014). Technology and globalization have changed our lives, as they have led to increased competition for talent. Thus, the potential growth of organizations worldwide depends on the ability of companies to ensure that the right people with the right skills are in the right place at the right time and focused on the right activities. For these reasons, talent management has been elevated to the top of strategic human resources management challenges, acquiring the highest priority across all organizations (Fowler, 2016).

Talent is a desirable quality in all human beings and organizations need workers with the right "Talent". The mere presence of talent does not ensure success in performance. Organizations need to invest in proper utilization of the talent for the advantage of the organization. In other words, organizations need to "Manage Talent" (Ansar and Baloch, 2018).Talent management can be defined as the systematic attraction, identification, development, engagement, retention, and deployment of those individuals who are of particular value to an organization (CIPD, 2020).

The ability to develop and implement integrated talent management is considered as the roadmap for organizational success in the 2020 workplace (Garr, 2012). Effective talent management policies and practices can result in more engaged employees and increased retention of them with the knock-on benefit on both employee productivity and talent retention. Nurse engagement and retention should always be on the 


\section{Nurses' Perception toward Talent Management and its Relationship to their Work Engagement and Retention}

minds of those in leadership (Hejase, Hejase, Mikdashi, and Farhat, 2016).

Work engagement is a solution to improve the overall functioning of organizations and individuals (Hoole and Bonnema, 2015). Understanding the elements contributing to nurse engagement is one of the most pressing issues for today's healthcare leaders. Whether from the perspective of losing and replacing high-performing nurses, retaining the wrong nurses, or the quality, safety, and patient experience costs to excellent care, engagement and its corollaries are big business with significant implications (King and Bradley, 2018).Having an engaged nursing workforce is one of the strategic imperatives for healthcare organizations in light of the multitude of challenges associated with the provision of quality healthcare (Othman, Nasurdin, 2019).

Moreover, talent management helps in retaining top talent through wellstructured onboarding practices that create higher levels of retention which saves the organization on its recruitment and performance management cost in the long run (human resources,2018). Retention of nurses is a global challenge (Drennan and Ross, 2019). Nursing retention defined as the ability to continue the employment of qualified individuals, that is, nurses and other health care providers/associates who other might leave the organization. The impact of this action is to maintain stability and enhance quality of care while reducing cost to the organization (Huber, 2014). For the healthcare organization, nurse retention results in positive consequences, such as nurse and job satisfaction and loyalty, a better quality of care, and increased client satisfaction. For the healthcare system, it contributes to a robust and adequate health workforce (WHO, 2018).

\section{Significance of the Study}

Talent management practices can be a strategy to attract, screen, select the right talent, engage, develop, deploy, lead and retain high potential and performer employees (Davies and Davies, 2010, Behera, 2016 and Thunnissen and Buttons, 2017). Additionally, talent management, employee engagement, and employee retention are factors that achieve the competitive advantage of an organization against its competitors. From investigators' clinical experience, it is observed that most nurses become not attached to their work thus increasing the shortage of nurses and turnover, so the present study will be conducted to assess nurses' perception toward talent management and its relation to their work engagement and retention.

\section{Purpose}

The purpose of this study was to assess nurses' perception of talent management and its relationship to their work engagement and retention.

\section{Research Questions}

1) What are the levels of nurses' perceptions of talent management?

2) What are the levels of work engagement among nurses?

3) What are the levels of nurses' retention at the hospital?

4) Is there a relationship between talent management, work engagement, and nurses' retention?

\section{Methods}

\section{Research Design}

A descriptive correlational research design was used for conducting this study

\section{Setting}

The study was conducted in the general departments and units in Menoufia University Hospital at Menoufia Governorate / Egypt. This 


\section{Nurses' Perception toward Talent Management and its Relationship to their Work Engagement and Retention}

hospital provides comprehensive medical and surgical services to patients, educational services to medical and nursing students as well as research activities. This hospital contains four buildings, a general hospital, a specialized emergency hospital, and a tumor hospital. The hospital has a capacity of 1000 beds. The hospital occupancy rate is $800-900$ patients / year.

\section{Sample}

Based on statistical administrative records of Hospital, (2018). There are 1200 nurses working in Menoufia University Hospital. The sample size was determined by using Solvin formula $(n=N / 1+(\mathrm{Ne} 2))$. Convenience sample of 400 nurses who accepted to participate in the study. Nurses whether males and females had to have more than 2 years experiences. The distribution of study sample at the selected departments / units $(\mathrm{N}=400)$ : 160 nurses from inpatient departments, 222 nurses from critical departments, and 18 nurses from the administration department with percentage of $(40.1 \%, 55.4 \%$ and $4.5 \%)$ respectively.

\section{Instruments}

Three instruments were used for data collection:

Instrument One: Talent management questionnaire. It consists of two parts:

- Part one: Social characteristics of participants (age, gender, qualification, occupation, and total years of experiences, hospital, and marital status).

- Part two: Talent management questionnaire
This questionnaire is adopted from El Nakhala (2013) and is modified by the investigator. It is used to examine nurses' perceptions of availability of talent management components at the workplace. The questionnaire consists of 31 items. It contains three theoretical dimensions of talent management; the first dimension is about the talent attraction that is composed of 10 items. The second dimension is about talent development that includes 10 items andthe third dimension is about talent retention that consists of 11 items. (Cronbach Alpha ranged from $0.877-0.939$ )

\section{Scoring system:}

The responses ranged from 1 (disagree), 2 (neutral), and 3 (agree). The score of each category will be summed up and converted into a percentage score. If total scores for nurses' talent management perception were $<60 \%$, it indicated that nurses' had low perception level of talent management. If total scores ranged from $60-75 \%$ nurses were considered to have moderate perception level of talent management and if nurses had the total scores $\geq 75 \%$, it indicated that nurses had a high perception level of talent management.

\section{Instrument Two: Utrecht Work Engagement (UWES):}

This structured questionnaire is adopted from Zaki(2017) who modified it based on the literature review related to Bakker and Demerouti,(2008). It aims to assess work engagement level among staff nurses. It includes 20 items that are divided into three dimensions; vigor (6 items), dedication (6 items) and absorption (8 items). ( cronbach's Alph .827).

\section{Scoring system:}

Subjects' responses were measured on a five-point Likert scale ranged from 


\section{Nurses' Perception toward Talent Management and its Relationship to their Work Engagement and Retention}

(1) never to (5) always. The scores of each dimension are summed up and converted into percent scores. If total scores of nurses' work engagement were $<60 \%$, it indicated that nurses' had a low level of work engagement. If total scores ranged from $60-75 \%$, nurses are considered to havea moderate level of work engagement and if nurses had the total scores $\geq 75 \%$, this indicated that nurses had a high level of work engagement

\section{Instrument Three: Nurses'}

\section{Retention Questionnaire}

It is developed by Safan and foazy (2017) to assess contributing factors of retention. These factors are grouped under the following four dimensions: salary and incentives (5 items), job contents (20 items), work environment (23 items), and organizational factors (4items). ( Cronbach Alpha 0.97).

\section{Scoring system}

The responses ranged from 1 (disagree), 2 (neutral), and 3 (agree). The score of each category will be summed up and converted into percent score as If total scores for nurses' retention were $<60 \%$ nurses were considered to have lowretention rate. If total scores ranged from $60-75 \%$ nurses were considered to have a moderate retention rate and if the total scores of nurses were $>75 \%$ nurses were considered to have a high retention rate.

\section{Validity of the instruments}

A Bilingual group of five experts (three professor and two assistant professors) were selected to test the content and face validity of instruments from the Nursing
Administration Department. No modifications were required.

\section{Procedure}

An official letter was sent from the Dean of the faculty of nursing Menoufia University to the director of Menoufia University Hospital explaining the purpose and method of data collection. The investigator explained the purpose of the study to every participant. The investigator was available for help to avoid any misinterpretations of questions during data collection. An oral consent was taken from each study subject. Data collection took about three months from beginning of Marh 2020 to the end of May 2020.The questionnaires were distributed during nurse's work hours. It took around 25-30 minutes from each study sample to fill in the questionnaire.

\section{Ethical considerations}

Approval was obtained from the Ethics Committee of the Faculty of Nursing, Menoufia University. The privacy and confidentiality of data were maintained and assured by getting participants' consent to participate in the research before data collection. Anonymity of participants was granted.

\section{Statistical analysis}

The collected data were organized, tabulated and statistically analyzed using SPSS (Statistical Package for Social Science) software statistical computer package version 26. For quantitative data, the range, mean and standard deviation were calculated. Comparison was done using Chisquare test $\left(\chi^{2}\right)$. For comparison between means for two variables in a sample, paired samples ttest was used.

\section{Results}




\section{Nurses' Perception toward Talent Management and its Relationship to their Work Engagement and Retention}

Table (1): Distribution of the studied nurses according to their personal characteristics $(n=400)$.

\begin{tabular}{|l|c|c|}
\hline \multirow{2}{*}{ Characteristics } & \multicolumn{2}{|c|}{ The studied nurses } \\
(n=400)
\end{tabular}

Table 1: represented distribution of the studied nurses according to their personal characteristics. More than two-fifths of staff nurses $(45.0 \%)$ ranged from 25 to less than 35 years old, the majority of them were female $(85.5 \%)$, and more than half of
Them (56.8\%) had technical nursing institute. About staff nurses' marital status, the majority of them(77.2\%) were married, more than one- fifth of staff nurses $(32.0 \%)$ had years of experience from five to less than ten years.

Table (2): Ranking of studied nurses according to their mean scores of talent management dimensions $(n=400)$.

\begin{tabular}{|c|c|c|c|c|c|c|}
\hline \multirow[b]{2}{*}{$\begin{array}{l}\text { Talent management } \\
\text { Dimensions }\end{array}$} & \multicolumn{6}{|c|}{ The studied nurses $(n=400)$} \\
\hline & $\begin{array}{l}\text { No of } \\
\text { items }\end{array}$ & Minimum & Maximum & Mean \pm SD & $\begin{array}{c}\text { Mean } \\
\text { Percentage } \\
\%\end{array}$ & Ranking \\
\hline 1. Talent attraction & 10 & 10 & 30 & $19.15 \pm 5.861$ & 63.83 & 2 \\
\hline 2. Talent development & 10 & 10 & 30 & $19.41 \pm 5.701$ & $\underline{64.70}$ & 1 \\
\hline 3. Talent retention & 11 & 11 & 33 & $18.07 \pm 4.608$ & $\underline{54.76}$ & 3 \\
\hline $\begin{array}{l}\text { Total talent } \\
\text { management score }\end{array}$ & 31 & 31 & 93 & & $3 \pm 14.677$ & \\
\hline
\end{tabular}




\section{Nurses' Perception toward Talent Management and its Relationship to their Work Engagement and Retention}

Table 2 demonstrated ranking of studied nurses according to their mean scores of talent management dimensions. As shown in the table, the total mean score of nurses' perceptions of talent management was 56.63 \pm 14.677 . The highest mean score was related to talent development dimension $19.41 \pm 5.701$ with a mean percentage of $64.70 \%$. Besides, the lowest mean score was related to talent retention $18.07 \pm 4.608$ with a mean percentage of $54.76 \%$.

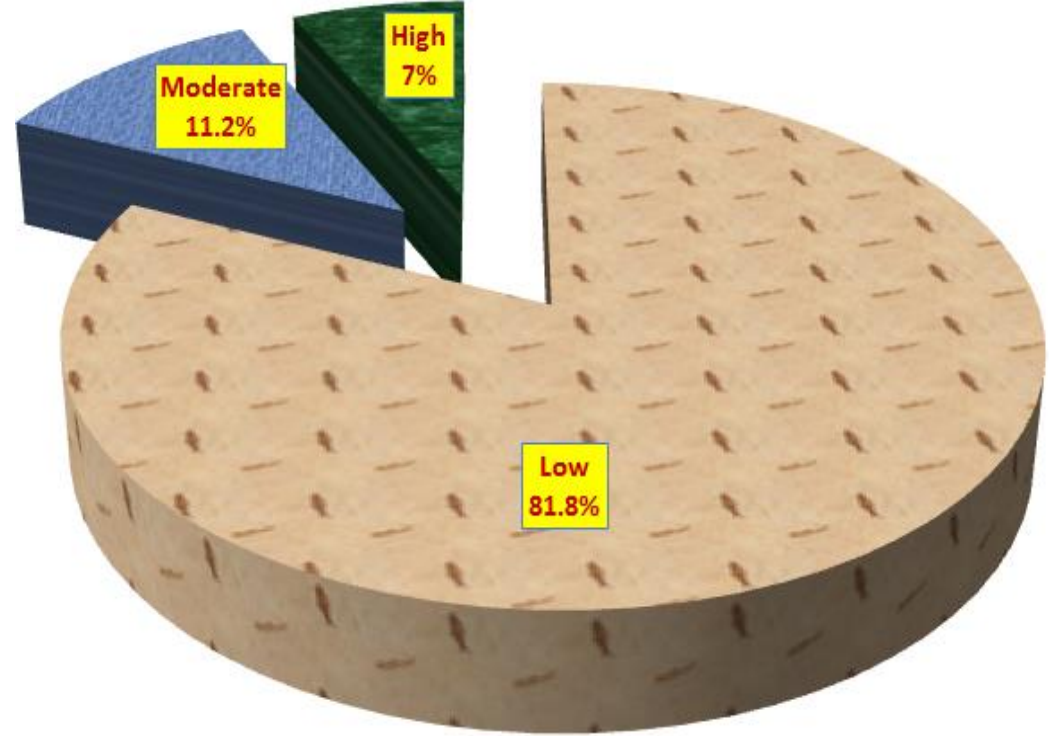

Figure 1 Percentage distribution of the studied nurses according to their total perception levels of talent management.

Figure 1 demonstrated the Percent distribution of the studied nurses according to their total perception levels of talent management. As shown in the figure, the majority of studied nurses had a lowperception level towards talent management with
$81.8 \%$. Also, $11.2 \%$ of studied nurses had a moderateperception level towards talent management, while only $7 \%$ of studied nurses had a highperception level towards talent management.

Table (3): Ranking of studied nurses according to their total mean score of work engagement $(n=400)$.

\begin{tabular}{|l|c|c|c|c|c|c||}
\hline \multirow{2}{*}{$\begin{array}{c}\text { Work engagement } \\
\text { Dimensions }\end{array}$} & \multicolumn{5}{|c|}{ The studied nurses (n=400) } \\
\cline { 2 - 7 } & $\begin{array}{c}\text { No of } \\
\text { Items }\end{array}$ & Minimum & Maximum & Mean \pm SD & $\begin{array}{c}\text { Mean } \\
\text { Percentage } \\
\%\end{array}$ & Ranking \\
\hline Vigor & 6 & 6 & 30 & $25.42 \pm 7.98$ & 63.55 & 2 \\
\hline Dedication & 6 & 6 & 30 & $20.27 \pm 6.65$ & 67.57 & 3 \\
\hline Absorption & 8 & 8 & 40 & $17.89 \pm 5.63$ & 59.63 & $63.57 \pm 18.35$ \\
\hline Total work & 20 & 20 & 100 & & & \\
\hline
\end{tabular}




\section{Nurses' Perception toward Talent Management and its Relationship to their Work Engagement and Retention}

Table 3 demonstrates ranking with mean scores of work engagement dimensions among studied nurses. As shown from the table the total mean score of nurses' level of work engagement was $63.57 \pm 18.35$. The highest mean score was related to the

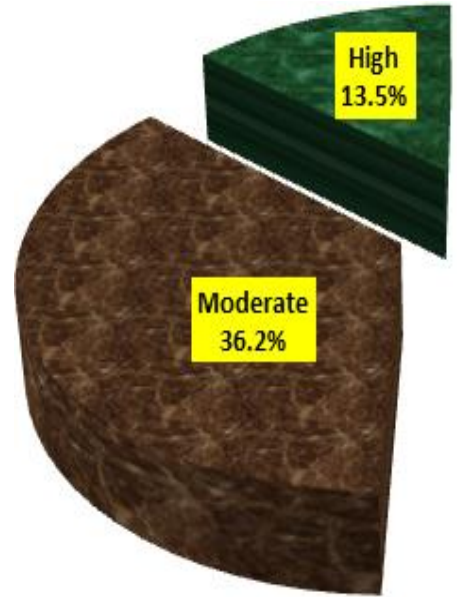

dedication dimension $20.27 \pm 6.65$ with a mean percent of $67.57 \%$. Also, the lowest mean score was related to absorption dimension $17.89 \pm 5.63$ with mean percent of $59.63 \%$.

Figure(2): Percentage distribution of the studied nurses according to their total level of work engagement.

Figure 2 llustrated the percent distribution of the studied nurses according to their total level of work engagement. As noticed from the figure, more than half of the studied nurses $(50.3 \%)$ had a lowlevel of work

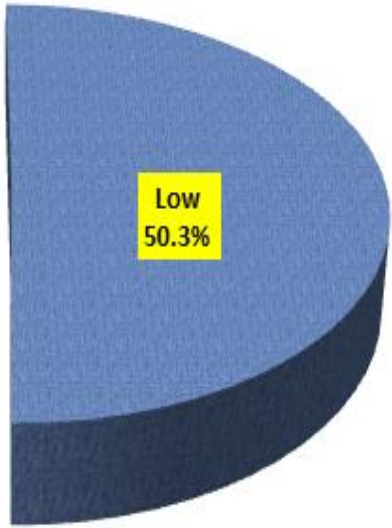

engagement. Also, almost one-third of studied nurses $(36.2 \%)$ had a moderatelevel of work engagement, while less than one-fifth of them $(13.5 \%)$ had a highlevel of work engagement.

Table (4): Ranking of studied nurses according to mean scores of contributing factors of retention among studied nurses $(n=400)$.

\begin{tabular}{|c|c|c|c|c|c|c|}
\hline \multirow{2}{*}{$\begin{array}{l}\text { Contributing factors } \\
\text { of retention } \\
\text { dimensions }\end{array}$} & \multicolumn{6}{|c|}{ The studied nurses $(n=400)$} \\
\hline & $\begin{array}{l}\text { No of } \\
\text { Items }\end{array}$ & Minimum & Maximum & Mean \pm SD & $\begin{array}{c}\text { Mean } \\
\text { percentage } \\
\% \\
\end{array}$ & Ranking \\
\hline Salary and incentive & 5 & 5 & 15 & $7.39 \pm 2.028$ & 49.27 & 4 \\
\hline Job content & 20 & 20 & 60 & $38.22 \pm 7.401$ & 63.70 & 2 \\
\hline Work environment & 23 & 23 & 69 & $48.36 \pm 8.317$ & 70.09 & 1 \\
\hline Organization & 4 & 4 & 12 & $7.29 \pm 1.645$ & 60.75 & 3 \\
\hline $\begin{array}{l}\text { Total contributing factors of } \\
\text { retention score }\end{array}$ & 52 & 52 & 156 & $101.26 \pm 15.699$ & & \\
\hline
\end{tabular}


Table 4 illustrates ranking of studied nurses according to mean scores of contributing factors of retention among studied nurses. As shown from the table, the total mean score of nurses' retention level was 101.26 \pm 15.699 . The first ranking with the highest mean

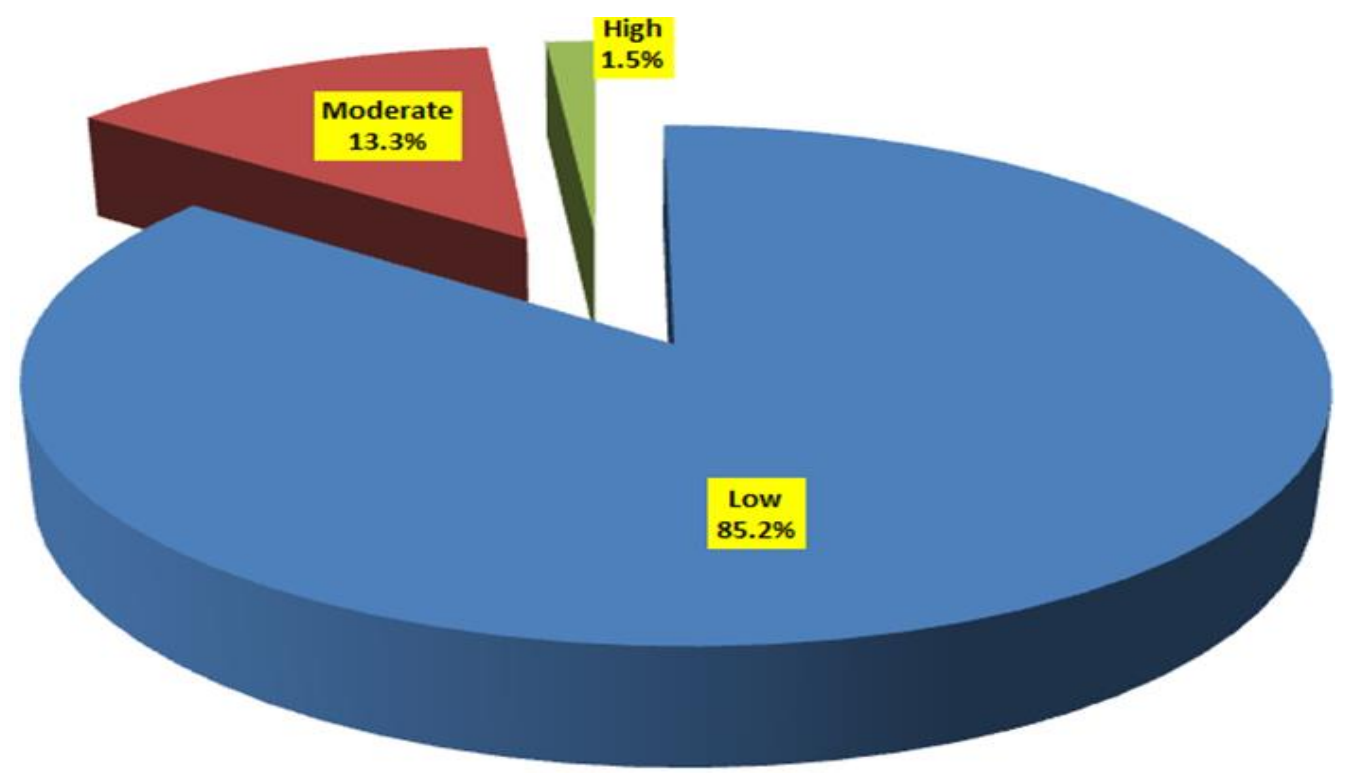

Figure (3): Percentage of the studied nurses according to their total level of retention.

Figure 3 demonstrates the percentage distribution of studied nurses according to their total level of retention. As shown in the figure, the majority of studied nurses $(85.2 \%)$ had score related to work environment dimension $48.36 \pm 8.317$ with a mean percentage of $70.09 \%$. Besides, the last ranking with the lowest mean score was related to salary and incentive dimension $7.39 \pm 2.028$ with a mean percentage of $49.27 \%$. a low level of retention. Also, $13.3 \%$ of studied nurses had a moderate level of retention, while only $1.5 \%$ of studied nurses had a high level of retention.

\section{Table (5): Correlation between talent management, work engagement, and} retention among studied nurses $(n=400)$.

\begin{tabular}{|c|c|c|}
\hline \multirow{2}{*}{ Study variables } & \multicolumn{2}{|c|}{ Talent } \\
& \multicolumn{2}{|c|}{ Management } \\
\cline { 2 - 3 } & $\mathbf{R}$ & p. values \\
\hline Work engagement & 0.653 & $0.000^{* *}$ \\
\hline Nurses retention & 0.436 & $0.000^{* *}$ \\
\hline
\end{tabular}

** Highly significant at level $\mathrm{P}<0.01$

Table 5 showed a correlation between studied nurses of talent management and their work engagement and retention. It showed that there was a highly positive statistically significant correlation between nurses' perception of talent management and their engagement and retention. 


\section{DISCUSSION}

For healthcare organizations, medical staffing is only as successful as its ability to engage and retain the best healthcare professionals. So organizations must be consistently vigilant of their employees' needs and must develop talent carefully to keep employees engaged and committed to their job (Dyson, 2015). Employee retention and talent management have been a critical issue for many organizations and a challenging situation for human resource managers. With high employee turnover, organizations always face the risk of lower productivity, decreased employee engagement, increased training costs, and an undesirable reputation of employee attrition. As a result, organizations nowadays are putting a lot of effort into talent management practices that encourage the employees to be fully engaged and take pride while working for their organization and so increase employee retention (Tamanna, 2018). This current study was conducted to assess nurses' perception toward talent management and its relationship to their work engagement and retention through answering the following questions; the 1st question was "What is the level of nurses' perceptions towards talent management?", the 2nd question was "What are the levels of work engagement among nurses?", the 3rd question was "What are the levels of nurses' retention at hospitals?", and finally the 4th question was "Is there a relationship between talent management, work engagement, and nurses' retention?". The current study showed that the majority of studied nurses had low perception toward talent management, whilea very small percentage of studied nurses had high perception toward talent management.

The result of current study was supported by Haines (2016) who conducted a study on" Talent management in nursing "revealed that the nurses had a low-level perception of talent management. Also, result of current study was incongruent with Elkady, Bassiouni, and Atalla (2019) who conducted a study on" Nurses' Perception about the Relationship between Talent Management and Organizational Commitment" indicated that student nurses at hospitals have a moderate level perception about talent management.

Additionally, the current study showed that the first ranking of talent management dimensions was related to the talent development dimension, followed by talent attraction, while the last ranking was talent retention. Thisstudy result was supported by Kheirkhah, Akbarpouran and Haqhani (2016) who conducted a study on" Relationship Between Talent Management and Organizational Commitment in Midwives". They revealed that the talent development dimension had the highest mean score, whereas the talent conservation dimension had the lowest mean score. Also, it was consistent with Humaid (2018) who conducted a study on" Talent Management and Organizational Performance: The Mediating Role of Employee Engagement" who revealed that talent retention was the last in ranking. 


\section{Nurses' Perception toward Talent Management and its Relationship to their Work Engagement and Retention}

On the contrary, it was inconsistent with Megri (2014) who conducted a study on" The Impact of Talent Management System on the Enterprise Performance" and revealed that talent attraction got the first ranking followed by talent retention, and finally talent development. Also, El Nakhla (2013) who conducted a study on" The Availability of Talent Management Components From Employees Perspectives" revealed that talent retention got the first ranking, then talent attraction, and finally the talent development.

The current study declared that less than one-fifth of staff nurses had high work engagement, while more than half of the studied nurses had a lowlevel of work engagement. In the same line,Eliwa (2019), who conducted a study on" perceived organizational support and its relation to work engagement among staff nurses" revealed that more than half of studied nurses had a lowlevel of work engagement. Also, Wang, Liu, Zou, Hao, and Hui (2017), who conducted a study on "Associations of Occupational Stressors, Perceived Organizational Support, and Psychological Capital with Work Engagement among Chinese Female Nurses" revealed that nurses had a low level of work engagement.

In contrast, Fountain (2016) who conducted a study on "Relationships among work engagement, drivers of engagement, and bullying acts in registered nurses working in hospital settings" revealed that nurses had a high level of work engagement. Additionally, Elhanafy (2018), who conducted a study on "Relationship between

Cyberloafing,

Organizational Justice, Work Engagement, and Organizational Trust among Nurses" revealed that nurses had a moderate level of work engagement.

The current study declared that the majority of studied nurses had a low level of retention, while a very small percentage of studied nurses had a high level of retention. This study result was supported by Onyango (2016) who conducted a study on "The influence of motivation and work environment on nurse retention: a case of Shalom Hospitals", and the study revealed that nurses at The Shalom group hospital had low retention level. While the result of the present study was incongruent with Safan and faozy, (2017) who conducted a study on "Relationship between Motivating Work Factors and Nurses' Retention in selected Hospitals at Shebin - Elkom /Hospital" and the study revealed that staff nurses at Menoufia university hospital at Shebin-ELkom had a moderate level of retention.

The current study showed that there was a highly statistically significant positive correlation between staff nurses' perception toward talent management, work engagement, and nurses' retention as reported by the studied nurses. This study result was supported by Ayub, (2017) who conducted a study on "the impact of talent management on employee engagement, and retention in achieving organizational performance" and revealed that talent management is a part of the overall strategy for organizations to engage and retain their employee talents.

At the same line, Budiana, Supriyati, and Wibowo,(2019) who conducted a study on "Talent Management Strategy of Employee Engagement". They concluded that there is a positive interlink between talent management and employee engagement. 


\section{Nurses' Perception toward Talent Management and its Relationship to their Work Engagement and Retention}

Results of the current study were consistent with Weerasinghe, (2017) who conducted a study on "Impact of talent management on employee retention" and proved that there's a positive impact of talent management on employee retention. Also, Elsaid (2017) who conducted a study on "An Exploratory Study on How Talent Management Affects Employee Retention and Job Satisfaction for Personnel Administration" revealed that there was a significant relationship between the components of talent management and employee retention as both training and development and job enrichment were found to have a significant impact on employee retention.

\section{Conclusion}

In the light of the current study findings, it was concluded that: the majority of studied nurses $(81.8 \%)$ had lowperception level towards talent management, (11.2\%) of studied nurses had moderate perception level, while only (7\%) of studied nurses had high perception level towards talent management. Also, more than half of studied nurses $(50.3 \%)$ had a low level of work engagement, almost one-third of studied nurses $(36.2 \%)$ had a moderate level, while less than onefifth of them $(13.5 \%)$ had a high level of work engagement. Additionally, the majority of studied nurses $(85.2 \%)$ had a low level of retention, $(13.3 \%)$ of studied nurses had a moderate level, while only $(1.5 \%)$ of studied nurses had a high level of retention. Finally, there was a highly positive statistically significant correlation between nurses' perception of talent management and their engagement and retention.

\section{Recommendations}

Based on the findings of this study, the following recommendations are proposed:

1- Hospital administrators should utilize talent management process to get experienced and qualified nurses and introduce talent management strategies into their strategic planning to remain competitive in today's healthcare market.

2- Training courses for nurse managers about how to improve hospital reputation through investment in their nurses.

3- Strengthening open communication by conducting schedules for nurses meeting with their managers to reach a high level of work engagement.

4- Provide an effective compensation program such as bonuses, flexible work hours, and fringe benefits to increase the commitment, work engagement, and retention of nurses.

5- Further researches are required to: 


\section{Nurses' Perception toward Talent Management and its Relationship to their Work Engagement and Retention}

Develop Education program for nurse managers about talent management, and its effect on productivity and quality of care.

\section{References}

Ansar, N. \&, Baloch, A. (2018). Talent and Talent Management: Definition and Issues. IBT Journal of Business Studies Volume 14(2), 213230, 2018.

Ayub, S (2017). The impact of talent management on employee engagement, and retention in achieving organizational performance.Faculty of Administrative Sciences Kotli. University of Azad Jammu and Kashmir, Pakistan.

Brunetto, Y. (2012). Study on Nurse Retention. The Journal of Nursing Scholarship, 34, 28-38.

Budiana, I., Supriyati, Y., \&Wibowo.(2019). Talent

Management Strategy of Employee

Engagement.International

Journal of Innovative

Technology and Exploring Engineering (IJITEE) ISSN: 2278-3075, Volume-8, Issue$6 \mathrm{C} 2$.

Chartered Institute of Personnel and Development (CIPD).( 2020). Talent management. Understand the changing context and benefits of talent management, and the key features of a talent management strategy. Available at https://www.cipd.co.uk/knowled ge/ strategy/ resourcing/talentfactsheet[Accessed on 28, Nov 2020].

Dehkordy, M., Haydari, H. \&Iravani, M .(2014). Study of Factors Affecting on Talent
Management Among Bank's Employees in Shahrekord.International Journal of Scientific Research. 8(2): 1-10.

Demerouti, E. \&Demerouti, E. (2008). Towards a Model of Work Engagement.Career Development International. 13. 209-223. $10.1108 / 13620430810870476$.

Drennan, V. \& Ross, F. (2019).Global nurse shortagesthe facts, the impact and action for change.British medical bulletin. 130 . 10.1093/bmb/ldz014.

Dyson, E. (2015). Medical staffing: how to engage and retain healthcare workers. Available at:https://www.peoplescout.com /insights/engage-and-retainhealthcare-workers/.access (12 Nov 2020).

El Nakhla, M. (2013). The Availability of Talent Management Components From Employees Perspectives. Master Thesis in Business Administration.Islamic University of Gaza.

Elhanafy, E. (2018). Relationship between Cyberloafing, Organizational Justice, Work Engagement and Organizational Trust among Nurses.

Eliwa, S.(2019). Perceived organizational support and its relation to work engagement among staff nurses.Nursing Admistration.Benha University Elkady, S., Bassiouni, N.\&Atalla, A.(2019). Nurses' Perception about the Relationship between Talent Management and Organizational Commitment. IOSR Journal of Nursing and Health Science (IOSR-JNHS) 


\section{Nurses' Perception toward Talent Management and its Relationship to their Work Engagement and Retention}

e-ISSN: 2320-1959.p- ISSN: 2320-1940 Volume 8, Issue 6 Ser. VIII. (Nov - Dec .2019), PP 41-52

.Www.iosrjournals.org

Elsaied, E.(2017). An Exploratory Study on How Talent Management Affects Employee Retention and Job Satisfaction for Personnel Administration in Ain Shams University Egypt. Journal of Management and Strategy.8(4).1-18.

Fountain, D. (2016).Relationship among work engagement, drivers of engagement, and bullying acts in registered nurses working in hospital setting (doctor of philosophy dissertation). ProQuest Dissertation Publishing.(UMI No, 10597139).

Fowler, L.(2016). Talent Management.Visionary talent Acquisition, Engaged Training and Development, Inspired Talent Succession.

Garr, S. (2012). Integrated talent management: A roadmap for success. Bersin\&Associates Research Bulletin.Retrieved from

https://www.towerswatson.com/ en/Insights/IC-Types/Survey-

Research Results/

2012/10/integrated-talentmanagement-a-roadmap-forsuccess.

Haines, S. (2016). Talent management in nursing: an exploratory case study of a large acute NHS trust. DHSci thesis, University of Nottingham.

Hejase, H., Hejase, A., Mikdashi, G.\&Farhat, Z. (2016). Talent Management Challenges: An Exploratory Assessment from Lebanon. International Journal of Business Management and Economic Research.Volume 7. pp. 504-520.

Hoole, C. \&Bonnema, J. (2015). Work engagement and meaningful work across generational cohorts. SA Journal of Human Resource Management/SA

TydskrifvirMenslikehulpbronb estuur, 13(1), Art.\#681, 11 pages.http://dx.doi.org/10.4102/ sajhrm.v13i1.681.

Hoole, C., \& Bonnema, J. (2015). Work engagement and meaningful work across generational cohorts. SA Journal of Human Resource Management/SA

TydskrifvirMenslikehulpbronb estuur, 13(1), Art.\#681, 11 pages.http://dx.doi.org/10.4102/ sajhrm. v13i1.681.

Huber, L. (2014). Leadership and management

principles.Leadership and Nursing Care Management. 5th ed. St Louis, MO: Elsevier; 2014:1-36.

Humaid, H. (2018). Talent Management and Organizational Performance: The Mediating Role of Employee Engagement. A Case Study Bank of Palestine in the Gaza Strip .Islamic University of Gaza

Kheirkhah, M., Akbarpouran, V.\&Haqhani, H. (2016). Relationship Between Talent Management and Organizational Commitment in Midwives Working in Iran University of Medical Sciences. Journal of Clientcentered Nursing Care. 2. 145152. 10.32598/jccnc.2.3.145.

King, C. \& Bradley, L.(2018). PRC National Nursing Engagement 
Report.Utilizing the PRC Nursing Quality Assessment Inventory.

Megri, Z. (2014). The Impact of Talent Management System on the EnterprisePerformance: a Study on a Sample of Workers in National Company of Juice and Canned-food Unit MANAA (Batna). Arab Economic And Business Journal, 9(2), p.156-165.

Safan \& faozy (2017). Relationship between Motivating Work Factors and Nurses' Retention in selected Hospitals at Shebin -Elkom.

Onyango, H. (2016). The influence of motivation and work environment on nurse retention: a case of Shalom Hospitals. Strathmore University.

Othman, N.\&Nasurdin, A.(2019). Job characteristics and staying engaged in work of nurses: Empirical evidence from Malaysia. International Journal of Nursing Sciences. 6 . 10.1016/ j.ijnss.2019.09.010.

Tamanna,A. (2018). Effect of Talent Management Practices and Organisational Performance on Employee Retention: Evidence From Indian It Firms.Department of Humanities \& Social SciencesJaypeeUniversityofEn gineeringandTechnology,Journ al of Internet Banking and Commerce.

Wang, X., Liu, L., Zou, F., Hao, J., $\& \mathrm{Wu}, \quad$ H.(2017).Associations of Occupational Stressors, Perceived Organizational Support, and Psychological Capital with Work Engagement among Chinese Female Nurses.
Biomed Res Int. 2017; 2017:5284628.

Weerasinghe, G.(2017). Impact of talent management on employee retention: A study carried out on travel agency in Sri Lanka. International Journal of Multidisciplinary Research and Development. Online ISSN: 2349-4182, Print ISSN: 2349-5979, Impact Factor: RJIF 5.72.

World Health Organization.(2018). WHO recommendation on recruitment and retention of staff in rural and remote areas.Retrieved from https://extranet.who.int/rhl/topic s/improving-health-system performance/whorecommendation-recruitmentand-retention-staffrural-andremote-areas.

Zaki, A. (2017). Perceived Nursing supervisor support and its Relation to Work Engagement and Turnover Intention among Staff Nurses. 